\title{
Etymologie ludowe w roli kreatorów kaszubskiej tożsamości etnicznej - Rozmòwa Pòlôcha z Kaszëbą Floriana Ceynowy
}

\begin{abstract}
Rogowska-Cybulska Ewa, Etymologie ludowe w roli kreatorów kaszubskiej tożsamości etnicznej - Rozmòwa Pòlôcha z Kaszëbą Floriana Ceynowy (Folk Etymologies in the Role of Creator of Kashubian Ethnic Identity - Rozmòwa Pòlôcha z Kaszëba by Florian Ceynowa). „Poznańskie Studia Slawistyczne” 8. Poznań 2015. Publishing House of the Poznań Society for the Advancement of the Arts and Sciences, pp. 153-165. ISSN 2084-3011.

The article presents folk etymologies in the work of Florian Ceynowa (1817-1881), who is the creator of the written version of the Kashubian language, entitled Rozmòwa Pòlôcha z Kaszëba (1850). Rozmòwa... is maintained in a form of dialogue which preaches the most important information about Kashubians. 30 folk etymologies written by Ceynowa, 3 of which are about the war and 27 about the Bible, serve - thanks to creating a positive picture of the 19th century Kashubia and Kashubians - the construction of Kashubian identity and prestige of the whole Kashubian community.
\end{abstract}

KeYwords: folk etymology; Kashubian language; Florian Ceynowa; Rozmòwa Pòlôcha z Kaszëbą; Kashubs

W świetle koncepcji izomorfizmu kultury i języka w planie funkcjonalnym i hierarchicznym, sformułowanej przez Nikitę I. Tołstoja, a także zgodnie z wyróżnionymi przez niego czterema paralelnymi układami typu język - kultura ${ }^{1}$ (Tołstoj 1992: 16) podnoszeniu statusu etnolektu z dialektu na język literacki towarzyszy przekształcanie kultury typu ludowego (obsługiwanej przez gwary, dysponujące tylko dwoma stylami: użytkowym i artystycznym - Bartmiński 1977: 8) w kulturę typu oficjalnego, elitarnego (której językiem jest język standardowy, mający wiele odmian

${ }^{1}$ Są to następujące układy: 1) język literacki - kultura elitarna, 2) mowa potoczna kultura masowa, 3) dialekty, gwary - kultura ludowa, 4) żargony - kultura tradycyjno-profesjonalna. 
stylistycznych). Zabieg ten nie polega jednak na całkowitej zmianie treści kulturowych, prowadziłoby to bowiem do zerwania ciągłości danej kultury. Budowaniu poczucia łączności kultury współczesnej z dawną kulturą ludową sprzyja raczej reinterpretacja i przekształcanie tego, co ludowe, w wyznacznik etniczności. Niekiedy dążenie do kreowania tożsamości etnicznej wiąże się nawet $\mathrm{z}$ tworzeniem pewnych brakujących elementów kultury ludowej, które mogłyby odegrać rolę ,znaków identyfikacyjnych, które pozwalają odróżniać swoich od obcych" (Szacka 2006: 51).

Efektem takiej właśnie kreacji są etymologie ludowe wprowadzone przez Floriana Stanisława Wenancjusza Ceynowę (1817-1881) na karty jego kaszubskojęzycznego utworu Rozmòwa Pòlôcha z Kaszëba napisónô przez s.p. Ksãdza Szmùka z Pùcka a do drëkù pòdónô przez Sëna Wòjkòjca ze Stawòszëna. Ceynowa, zwany „budzicielem Kaszubów” i „ojcem regionalizmu kaszubskiego", był twórcą pisanej wersji kaszubszczyzny, w której uprawiał działalność literacką, naukową i publicystyczną, pisząc po kaszubsku przede wszystkim o folklorze, polityce, filozofii, etnografii, historii i medycynie; ,,pomnażał kaszubskie piśmiennictwo w tym języku, wzmacniając m.in. poczucie tożsamości i budując dumę szczepową" (Treder 2007: 12). Wydana w 1850 roku Rozmòwa Pòlôcha z Kaszëba to jeden z pierwszych utworów literackich Ceynowy. Choć autor określił go jako „krotochvilne dzełko” (Treder 2007: 12), owa „krotochwilna” czy - powtarzając za Jerzym Sampem - ironiczno-groteskowa (Samp 1988: 10) forma kryje poważniejsze problemy. Utwór ma formę dialogu, który Jerzy Treder nazywa „podaniowo-katechizmowym” (Treder 2007: 21). Ceynowa wkłada w usta Kaszuby namawiającego Polaka, by ten został Kaszubą, podstawowe informacje o jego małej ojczyźnie. Składają się na nie różne wiadomości o charakterze etnograficznym (zwłaszcza w sensie, jaki nadawano temu przymiotnikowi w XIX w.):

Rozmowa przedstawia - ustami Kaszuby, oczywiście, po kaszubsku (z idiomatyką i przysłowiami) - literacką wypowiedź w takich zakresach, jak nazwa Kaszubi i ich

${ }^{2}$ Pierwsze wydanie Rozmòwë Pòlôcha z Kaszëba ukazało się pod kryptonimem ks. Szmuka z Pucka, autorstwo Ceynowy nie ulega jednak wątpliwości (Treder 2007: 15-18). Dzięki tej mistyfikacji autor pozorował powstanie utworu w końcu XVIII wieku, czym wydłużał o pół wieku historię piśmiennictwa kaszubskiego. Ceynowa, podpisując swe utwory, często stosował kryptonimy, m.in.: C.F., Kaszuba, Ein Slawe, Wójkasén ze Sławoszéna, Sin Wójkwójca ze Sławôszena, stôreho Kovôla sin ze Stawoszéna i Gburzczón (Treder 2006: 35). 
grupy, położenie i granice Kaszub, stare dokumenty, Biblia i piśmiennictwo, dzieje Kaszub (tu ich obraz jako staro- i nowotestamentowej Palestyny) czy Ziemi Obiecanej, Izraela i raju (...), a zatem też nazwy (z ich genezą) miejscowości, puszcz i błot, rzek, jezior i mórz owej krainy (...), status mowy (języka) Kaszubów na tle innych słowiańskich i indoeuropejskich, a nawet semickich (...), jej oryginalność i możliwość nauczenia się, (...) biblijny rodowód (stworzenia) Kaszuby (...), podział i współżycie Kaszubów oraz Polaków (...) (Treder 2007: 24).

Ważną rolę w przybliżaniu Polakowi i - za jego pośrednictwem czytelnikowi Rozmòwë... wiedzy o Kaszubach (krainie) i Kaszubach (jej mieszkańcach) oraz w budowaniu prestiżu kultury kaszubskiej (Zieniukowa 2003) odgrywają wykreowane przez Ceynowę etymologie ludowe, dotyczące przytaczanych w różnych fragmentach tego utworu kaszubskich nazw miast i wsi, krain, rzek, gór, błot, etnonimów i antroponimów.

Etymologia ludowa, nazywana też etymologią asocjacyjną, fantazyjną, folklorystyczną, naiwną, nienaukową, potoczną i synchroniczną, a także reinterpretacją etymologiczną i pseudoetymologią (Malinowski 1885; 1888; 1891; Cienkowski 1972; Michow 2008; Zierhofferowa, Zierhoffer 2012; 2013), „polega na dążeniu do zrozumienia i czasem przekształcania wyrazów niezrozumiałych przez łączenie ich z wyrazami znanymi i zrozumiałymi” (Cienkowski 1992: 141). Dla uwypuklenia różnicy w stosunku do etymologii naukowej, zwanej też historyczną, bywa definiowana jako „błędne, sprzeczne z dokumentacją językoznawczą wyjaśnienie pochodzenia określonego wyrazu (...)" (Kostkiewiczowa 1988: 132). Największym zainteresowaniem ludowych reinterpretatorów cieszą się nazwy własne, zwłaszcza nazwy miejscowości, co Bogdan Walczak tłumaczy następująco:

nazwy własne, pozbawione znaczenia takiego, jakie przysługuje wyrazom pospolitym (pierwotne znaczenie, żywe jeszcze w momencie powstawania nazwy, szybko się zaciera i nazwa nie znaczy tak, jak wyraz pospolity, lecz jedynie oznacza, „nazywa” miejsce czy osobę), zawsze w szczególny sposób intrygowały użytkowników języka (którzy usiłowali się tego pierwotnego, zatartego znaczenia dokopać) (Walczak 1999: 194).

Jan Miodek uważa tworzenie etymologii ludowych nazw miejscowości za ,zasługujące na podziw ludzkie dążenie do prawdy” (Miodek 2002). Henryk Duda i Mariusz Koper podkreślają, że „chęć interpretacji onimów wynikała zarówno z własnej ciekawości, jak też z obowiązku przekazu tradycji następnym pokoleniom” (Duda, Koper 2009: 82). Zdaniem Elżbiety 
Michow, znajomość etymologii ludowych nazw miejscowych „łączy się z pojęciem małej ojczyzny, z uczestnictwem w świecie tradycji i zwyczajów lokalnej wspólnoty" (Michow 2008: 10).

Termin etymologia ludowa „tłumaczy się częstością i wielką skalą tego zjawiska wśród mas ludowych" (Kania, Tokarski 1984: 154) i ten właśnie fakt Florian Ceynowa wykorzystał w Rozmòwie Pòlôcha z Ka$s z e ̈ b a$, inkrustując wybrane fragmenty tego dzieła etymologiami ludowymi kaszubskich toponimów i antroponimów. Do etymologii ludowych Ceynowy odnosi się szczególnie konstatacja J. Tredera, że „forma wypowiedzi pozwala mu łączyć dawny folklor z tworzonym przez siebie nowym, asymilującym już elementy kultury chrześcijańskiej” (Treder 2007: 23-24). Wzorując się na etymologiach naiwnych znanych z kultury ludowej, autor Rozmòwë... posłużył się tą formą do wykreowania określonego, „lepszego" obrazu Kaszub i Kaszubów, bez zrywania z ludowymi korzeniami kulturowymi.

Ceynowa w Rozmòwie Pòlôcha z Kaszëba na dwa sposoby buduje prestiż kultury kaszubskiej za pomocą autorskich etymologii ludowych. Pierwszy z nich można zaobserwować tylko w trzech etymologiach przytoczonych na początku tego utworu, a polega on na bezpośrednim odwoływaniu się w podstawach nominacyjnych reetymologizowanych onimów do pojęcia sławy wojennej. Naśladuje tu Ceynowa upodobanie autentycznych ludowych etymologów do wywodzenia toponimów od wyrazów należących do leksyki wojennej, wynikające zapewne z zawężania w potocznym obrazie świata historii do historii politycznej, a tej - do dziejów wojen. Podobnie jak ludowym reinterpretatorom tematyka wojenna pozwala mu wprowadzać do opowieści etymologicznych motyw waleczności, heroizmu i patriotyzmu przodków, co nobilituje również ich współczesnych potomków (Rogowska-Cybulska 2013: 88).

Reinterpretacji z wykorzystaniem wyrazów należących do pola semantycznego wojny dokonuje Ceynowa w stosunku do onimów szczególnie ważnych dla tożsamości kaszubskiej (Rzetelska-Feleszko 2003: 50), również jego własnej. Budowaniu i utrwaleniu samoidentyfikacji wspólnoty służy przede wszystkim etymologia ludowa nazwy kaszubskiej grupy etnicznej. Wywodzi ją Ceynowa - poprzez postać Każebi - od zwrotu kôże bic, nadając jej wykładnię onomastyczną 'lud, który, gdy mu się kôże bic wrogów, wszëtczëch ùbije’: „Fejn Kaszëbi, chtërny przez swòje mãstwò, 
co je napisóné w ksãdze Chronikòrum kaszëbsczé, tomie II, zeszëce 30. na stronie 179, a to w te słowa: Nama jich kôże bic, a wszëtczëch ùbijemë - wieczny sobie zaszczët ù całégò swiata zrobilë. Stąd pòwstało miono nasze Każebi czëlë Kaszëbi”' (Ceynowa 2007: 126-127).

Drugim toponimem, którego genezę Ceynowa tłumaczy słowem związanym z wojną, jest Sławoszëno, nazwa jego rodzinnej miejscowości. Swą prywatną mitologię, podniesioną tu do rangi ogólnokaszubskiej, opiera autor Rozmòwë... na położeniu Sławoszyna w pobliżu pola bitwy pod Świecinem, na którym w 1462 roku wojska polskie pokonały Krzyżaków, oraz na nadaniu z tego powodu nazwie tej miejscowości wykładni semantycznej 'miejsce, które mô pò wieczné czasë naszã sławã głosëc ë sława słënąc': „ë wies, niedalek bòjowiszcza leżącô, Sławòszëno, mô pò wieczné czasë naszã sławã głosëc ë sławą słënąc" (Ceynowa 2007: 127).

Trzeci onim należący do tej grupy to antroponim Swiatopôtk, odnoszący się do Świętopełka Wielkiego, wybitnego księcia Pomorza Gdańskiego, któremu Ceynowa poświęcił jedną ze swoich Trzech rosprav, pt. Xąże Svjętopótk (1850). Imię to zyskało w Rozmòwie... wykładnię semantyczną 'książę kaszubski, który wojował, jakbë cati swiat chcôt pôtknac': ,a nasz Ksążã Swiatopôłk, co pòtemù tak wòjowôł, jakbë całi swiat chcôł pôłknąc, za to nama nadôł różné diplomë, chtërne jesz pò dzysdzéń leżą na rôtëszu pùcczim jakò w stołecznym miesce zemi kaszëbsczi” (Ceynowa 2007: 127).

Pozostałe dwadzieścia siedem etymologii ludowych Floriana Ceynowy stanowi element zastosowanej w Rozmòwie... stylizacji biblijnej ${ }^{3}$, ukazującej „starożytność krainy i zarazem jej głęboką chrześcijańskość jako miejsce zamieszkania ludu wybranego" (Treder 2007: 32). Już na drugie pytanie Polaka: „Co to są te Kaszuby?”, Kaszuba odpowiada: ,je to krôj òd Bòga z dôwna òbiecóny, krôj swiãti, w chtërnym mlékò ë miód płënie, a lëdze, co w tim kraju mieszkają, nazéwają sã lëdzama wëbrónyma, pòchòdzącyma òd Jizraela dôwnégò" (Ceynowa 2007: 126).

Figura Kaszub jako starożytnej Palestyny przewija się przez cały utwór, służąc do opisu granic tej krainy, jej geografii i sytuacji społeczno-politycznej. Ceynowa kształtuje analogie między Kaszubami a Ziemią

${ }^{3} \mathrm{O}$ motywie Pomorza jako ziemi obiecanej w literaturze i tradycji pomorsko-kaszubskiej cf. Borzyszkowski 2003. 
Świętą, ukazując między innymi podobieństwa realiów kaszubskich i palestyńskich:

P. A Pioter, apostoł, skąd był rodem?

K. Òd mòrza, z Krëszwicë, chtërna to wies rëbackô jesz pò dzysdzén sã tim chôłpi.

P. A Paweł skąd?

K. Z Bólszewa, bò tam bëła tej bóżnica żëdowskô, a òn béł jich nôwëższim szkólnym (Ceynowa 2007:133).

Przede wszystkim jednak autor Rozmòwë... tworzy w tym celu etymologie ludowe kaszubskich nazw miejscowości, krain, rzek, błot i gór ${ }^{4}$. J. Treder charakteryzuje je następująco:

Traktuje tu owe objaśnienia żartobliwie, dopasowując je do fabuły czy wręcz czerpiąc z nich pomysły do jej rozwijania. Przypomina to teksty folklorystyczne o tematyce etiologicznej, które wiarygodnym jednocześnie czynią sam zabieg biblijnego ujęcia Kaszub: dzieje ich giną w mrokach, dziś ów naród wybrany jest w niewoli (pruskiej), Kaszubi są głęboko religijni, wiodą spokojne życie wiejskie i zdrowe moralnie, w jakimś stopniu jakby pierwotne? Na biblijne ujęcie Kaszub bezpośredni wpływ mogła mieć Kalwaria w Wejherowie, a może także nazwy ze źródeł w rodzaju wymienionej Bożejstopki (1281) (Treder 2007: 26).

W ramach stylizacji Kaszub na Ziemię Świętą stosuje Ceynowa dwa rodzaje etymologii ludowej, reinterpretując etymologizowane onimy jako pochodzące od nazw własnych oraz od wyrazów pospolitych. Z klasyfikacją tą krzyżuje się podział efektów reinterpretowania kaszubskich toponimów - ze względu na typy strukturalne nazw miejscowych wyróżniane w świetle etymologii naukowej (Rospond 1957) - na nazwy prymarne i nazwy sekundarne.

Do toponimów pochodzących w świetle autorskiej etymologii ludowej Floriana Ceynowy od nazw własnych należą nazwy kaszubskie wyprowadzane przez niego od podobnie brzmiących nazw funkcjonujących w Biblii i w ogóle w historii starożytnej. Powoływanie na wtórną podstawę onomazjologiczną reetymologizowanych onimów kaszubskich nazw biblijnych i innych antycznych jest możliwe dzięki bagatelizowaniu - co charakterystyczne także dla autentycznych ludowych reinterpretacji - różnic fonetycznych między zestawianymi ze sobą nazwami.

\footnotetext{
${ }^{4} \mathrm{O}$ nazwach biblijnych w topografii Kaszub cf. Treder 1981.
} 
Jako nazwy prymarne Ceynowa wywodzi w Rozmòwie... następujące nazwy kaszubskie od następujących nazw biblijnych lub innych starożytnych:

- nazwę miasta Bëtowò (w wersji nieznormalizowanej Betovo) od hebrajskiego miasta Betlejem (Bettlehem) (wspólne głoski to $B, e, t / t t$ ):

P. A słuchajże, mój kochany, gdzie się też Chrystus urodził? Wszakże prawda, że w Bettlehem.

K. Prôwda, Panie, w Bettlehem hebrajsczim, a kaszëbsczim Bëtowie. Bò Bettlehem nazéwô sã pò naszémù, jak më wiérnie przekłôdómë, Bëtowò; a tam òn sã ùrodzył (Ceynowa 2007: 132-133);

- nazwę miasta Gduńsk (Gdańsk) od nazwy starożytnego miasta Gaza (wspólne głoski to $G, a / a, z / s$ ): „Grańce kaszëbsczé jidą, pòcząwszë òd Gduńska, starożëtnégò Gaza, Górą Libańską" (Ceynowa 2007: 127);

- nazwę kaszubskiej wsi Gniéżdżewò (Gnjeżdżevo) od nazwy biblijnego jeziora Genezaret (wspólne głoski to $G, n j / n, e, z / \dot{z}$ ): „Blëzë mòrza je Genezaret, co pò naszémù sã nazéwô Gniéżdżewò. Kò jednak mùsôł Genezaret bec blëzë mòrza, bò mómë w pismie, że Christus chòdzył przë Mòrzu Genezarecczim. Dlôtegò Wpón jesz pò dzysdzéń niedalek naszégò Gniéżdżewa widzysz mòrze, zazwëczôj Môłim zwóné” (Ceynowa 2007: 134);

- nazwę kaszubskiej wsi Kôrtoszëno (Kortoszeno) od nazwy starożytnego miasta-państwa Kartagina (wspólne głoski to $K, r, t, n$ ):

P. A Kartagina, gdzie też jest?

P. Kartagina nazéwô sã pò naszémù Kòpenhôga, miasto jesz pò dzysdzéń wiôldżi handel prowadzącé. Niechtërny mieszkańcé Kôrtoszëna ùwôżają Kôrtoszëno za Kartaginã, co leżi niedalek Żarnówca, blëzë Gór Karlëkowsczëch (Ceynowa 2007: 135);

- nazwę kaszubskich błot Karwia (Karvja) od łacińskiej nazwy Charawia (Charavia) (wspólne głoski to $K / C h, a, r, v i / j, a)$ :

P. Mój kòchany Kaszubò, powiedz mi też, gdzie na waszej ziemi są owe pùszcze, przez które Izraelici przechodzili i w których się 40 lat bawili?

K. Tak, mój panie, mòji przódkòwie bëlë na pùszczi, chtërnô sã nazewô Charawia pò łacënie, a terôz jã Kaszëbi zowią w różnëch miescach różnie, ale główną czãsc jednak përzinkã z łacyńska Karwią, czëlë Karwiańsczim Błotã (Ceynowa 2007: 130);

- nazwę krzyżackiego miasta Marienburg 'Malbork' od nazwy izraelskiego miasta Samaria (Samarija) (wspólne głoski to $M / m, a, r, i / j$ ): 
„Grańce kaszëbsczé jidą, pòcząwszë òd Gduńska (...) przë Samarii, to je Marienbùrgù dzysészim, czëlë zemi malbòrsczi do Gduńska" (Ceynowa 2007: 128);

- nazwę obecnej dzielnicy Wejherowa Nańc 'Nanice' (Nanc) od biblijnego miasta Najim (Naim) (wspólne głoski to $N, a$ ): „Pón nierôz z ewanielëji czuł, że ùmarłégò nieslë z Najim, chtërnégò Christus wskrzesył: a to miasteczkò je, terôz chòcle wsą, ù nas ë nazëwô są pò naszémù Nańc" (Ceynowa 2007: 134);

- nazwę (zemia) prëskô - od nazwy prowincji Persjô (wspólne głoski to $P, r, \ddot{e} / e, s)$, „tu nad tą wòdą bëła Frigiô, prowincjô Persji, czëlë zemi prësczi" (Ceynowa 2007: 130);

- nazwę kaszubskiego miasta Rëmiô (Remjo) od łacińskiej nazwy Roma ${ }^{5}$ 'Rzym' (wspólne głoski to $R, m i / m$ ):

\section{P. A Rzym jest daleko od was?}

K. Ale dosc dalek, bò Rzim nazéwô sã pò naszémù Piotrowò, czëlë Piotrogarda (Petersburg) pò Piotrze; abò, jak niejedny z Rëmi chcą, Rëmiô, co leżi niedalek òd traktu ze Gduńska do Jerozolëmë (Ceynowa 2007: 135);

- nazwę kaszubskiej wsi Swôrzewò (Svorzewo) od nazwy izraelskiego miasta Samaria (Samarija) (wspólne głoski to $S, r z / r$ ): „W nen sóm spòsób mëszlą swôrzewianie, że dôwnô Samariô je Swôrzewò" (Ceynowa 2007: 135);

- nazwę kaszubskiego miasta Wejerowò (Vejheropolis, Vejherowo) od nazwy miasta Jerozolëma (Jerozolema) (wspólne głoski to $j / J, e, r, o, o, l$ ):

Wiész téż Wpón dobrze, że w nowi Jerozolëmie je Christus ùmãczony. Ta Jerozolëma je ù nas, w naszëch Kaszëbach, ë nazéwô sã terôz Wejheropolis, Wejerowò abò Nowé Miasto. Jeszlë są WPón chcesz ó prôwdze przekónac, to tej le tam jidzë. A ùzdrzisz nã słôwną brómã, ògród Jecemańsczi, czëlë ògrójc, rzékã Cedrón, dóm Annasza ë Kajfasza, nã smrodlëwą piwnicã, Piłôta ë Heroda pałace, nen słôwny rôtësz, także drogã, chtërną Christus z krziża szedł na Górã Kalwarijską, dze jegò ùkrziżowelë, ë grób, w chtëren jegò złożëlë (Ceynowa 2007: 134-135).

Wśród kaszubskich onimów wywodzonych przez Ceynowę od nazw własnych biblijnych lub innych antycznych wyjątkowy charakter ma

5 „Skojarzenie z Roma 'Rzym' i dalej ze stolicą Piotrową - dla wtórnych zapisów Romna (Kronika oliwska), Roml(i)a (1584)” (Treder 2007: 135). 
oronim Górë Kòlibsczé, stanowi on bowiem jedyną w tej grupie nazwę sekundarną. Zdaniem autora Rozmòwë..., człon przymiotnikowy Kòlibsczé został rzekomo utworzony przyrostkiem kò- od przymiotnika Libańsczi, wchodzącego w skład oronimu Góra Libańskô: „Grańce kaszëbsczé jidą (...) Górą Libańską, a pò naszémù Górama Kòlibsczima, bò me baro rôd kò dodajemë" (Ceynowa 2007: 127).

Kaszubskie toponimy, które ze względu na podstawę onomazjologiczną dobraną przez Ceynowę pochodzą od apelatywów związanych z historią biblijną, należą głównie do nazw sekundarnych. Autor Rozmòwë... wykreował dla nich następujące wykładnie onomastyczne:

- dla nazwy Celbòwò - „miejscowość, w której mieściło się cło ewangelisty Mateusza”: „A pò niechtërnym czasu, jak ju [miasto Pùck] bëło znacznym miastã, bëła w nim akcyza, czëlë cło, przë chtërnym sedzôł Mateùsz, ewanielista, człowiek dosc pismienny, co jegò sobie Chrustus za ùcznia przëbrôł, jak mómë w naszim stôrim òpisaniu. A że to cło, czëlë col sã głównie przë brómie kù pôłniowi òdbiérało, dosta stąd jedna wies, blëze leżąc miono Celbòwò" (Ceynowa 2007: 133);

- dla nazwy Chiloniô - „miejsce, gdzie naród wybrany chilit sã już w wędrówce przez pustynię ze zmęczenia”: „W Grabówkù narżnãlë òni [tj. lud pògańsczi ë żëdowsczi] sobie grabowëch czijów ë palëc, ale mimò tegò w Chiloni ju wiele z nich sã le tak chilëło" (Ceynowa 2007: 131);

- dla nazwy Cechòcëno - „Jerichò, czyli miejsce, w którym naród wybrany bardzo sã ceszil”: „na òstatkù trafilë òni [tj. lud pògańsczi ë żëdowsczi] do Jerichò, pò naszémù Cechòcëna, a to dlôtegò je tak przezwelë, bò tu sã baro ceszëlë’ (Ceynowa 2007: 132);

- dla nazwy Cësowa - „miejsce, w którym członkowie narodu wybranego w drodze przez pustynię musieli ze zmęczenia jeden drugiego cësnac, czyli pchać”: „W Grabówkù narżnãlë òni [tj. lud pògańsczi ë żëdowsczi] sobie grabòwëch czijów ë palëc, (...) a przë Cësowi mùszôł jeden drëdżegò dali cësnąc" (Ceynowa 2007: 131);

- dla nazwy Grabówk - „miejsce, w którym przedstawiciele narodu wybranego w wędrówce przez pustynię nacięli sobie grabòwëch kijów”: „W Grabówkù narżnãlë òni [tj. lud pògańsczi ë żëdowsczi] sobie grabòwëch czijów ë palëc" (Ceynowa 2007: 131); 
- dla nazwy Kãpino - „loco campestri, czyli miejsce na równinie”:

Je ù nas niedalek Jerozolëmë, czëlë Nowégò Miasta no miesce, ò chtërnym mómë: „Stetit Jezus in loco campestri”. To miesce nazéwô są terôz Kãpino; ë jesz dzysdzéń kòżdi przechòdzący tam wstąpi, abò dlô ùgaszeniô pragniącczi, abò na noclég, abò téż na jaką rozriwkã. Na tim mòlu ë Jezus, jak szedł do Jerozolëmë ze Sławoszëna przez Bòżąstopkã, chtërną miedzë Mechòwã a Piôsznicą w kamieniu wecësnioną widzymë, stanął (Ceynowa 2007: 135-136);

- dla nazwy Kòlibczi - „miejsce, gdzie naród wybrany w wędrówce przez pustynię kòlibôł sã ze zmęczenia”: ,ale w Kòlibkach bëlë òni [tj. lud pògańsczi ë żëdowsczi] ju tak zmãczony, że sã le kòlibelë” (Ceynowa 2007: 131);

- dla nazwy Krziżacë - „Filistyni, bo byli krziżã dla Kaszubów”: „Grańce kaszëbsczé jidą, pòcząwszë òd Gduńska, (...) nad grańcą filistińską, czëlë krzëżacką, bò ten naród béł krziżã dlô Kaszëbów" (Ceynowa 2007: 128);

- dla nazwy Plutnica - „Jordan, czyli rzeka, w której naród wybrany òstôł òd grzéchów òpłókany”: „Do Môłégò Mòrza wpôdô rzéka Jordan, co sã pò naszémù Plutnicą zowie; a to dlôtegò, że tu lud pògańsczi ë żëdowsczi òstôł òd grzéchów òpłókany" (Ceynowa 2007: 131);

- dla nazwy Pùck - „miejsce, w którym Chrystus powiedział do Piotra: Pùc za mną": „Cze Pioter łowił rebë na mórzu, tej przëszedł Christus ë rzekł do niegò: «Piotrze, pùc za mną», ë to do trzecy rizë pòwtôrzôł; a stąd to miasto dostało miono Pùck, chtërnégò przedtim ni miało" (Ceynowa 2007: 133);

- dla nazwy Reda - ,miejsce, w którym przedstawiciele narodu wybranego nie zbudowali mostu przez rzekę, ale redelë, czyli brodzili”: „Ùceszony nie delë òni sobie czasu, abë przez rzekã kù Jerozolëmie mòst wëstawilë, le redelë, skąd rzéka ë wies Reda wòje miono wzãlë” (Ceynowa 2007: 132);

- dla nazwy Sopot (Copot) - „miejsce, w którym naród wybrany musiał sã ze zmęczenia copnac, czyli cofnąć, na posiłek”: „ale w Kòlibkach bëlë òni [tj. lud pògańsczi ë żëdowsczi] ju tak zmãczony, że (...) mùszëlë sã na pòsyłk do Sopòtu copnąc" (Ceynowa 2007: 131);

- dla nazwy Smiechòwò - „miejsce smiéchù narodu wybranego”: „A że coraz barżi miesce płaczu smiéch zajmòwôł, pòkazëje wies Smiéchowa" (Ceynowa 2007: 132). 
Wśród nazw objaśnianych przez Ceynowę jako „biblijne” odapelatywne są również trzy nazwy prymarne:

- Mòstë, o wykładni semantycznej „miejsce, w którym pasterze zbudowali narodowi wybranemu most”: „Pòtemù przëszlë òni do błota Zamòstnègò, dze sã miele dróbkã lepi, bò tu natrafilë wiele pasturzi, co dobëtk paslë ë nimògącë naszim przódkóm stawic òporã, jich dobrze pòczestowelë ë jima mòst przez rzekã zbùdowele, abë sã tëch nieproszonëch gòscy jak nôrëchli ze swi wédë pòzbëc. Stąd pòzwã Mòstë ë to całé błoto swòje miono" (Ceynowa 2007: 131-132);

- Òliwa, o wykładni semantycznej „miejsce, w którym naród wybrany miał jeszcze w wędrówce przez pustynię oliwę”: „tak w Òliwie pòsôdelë òni [tj. lud pògańsczi ë żëdowsczi] jesz òliwã" (Ceynowa 2007: 131);

- Zdrada, o wykładni semantycznej „miejsce, w którym wysłannicy Mojżesza zdradzili go”: „Cze Mòjżesz wësłôł òrãdowników, co bë sã wëwiadowelë ò zemi òbiecóny, tej jich zdradzëlë. Na tã pamiątkã ùzdrzisz Wpón pôrã kôt, przë ti pùszczi wëstawionëch, co sã nazéwają Zdradą" (Ceynowa 2007: 132).

Funkcję biblijnych etymologii ludowych Ceynowy J. Treder charakteryzuje na szerszym tle biblijnej stylizacji Kaszub następująco: „starożytność i osobliwość mowy, nazewnictwo o długim rodowodzie, ujęcie Kaszub jako biblijnej Palestyny i miejsce ukrzyżowania Jezusa (Kalwaria Wejherowska) itp. - wszystko to służy zarazem podniesieniu wartości Kaszub i Kaszubów, co niewątpliwie jest zamierzoną odpowiedzią na ich deprecjonujący wizerunek w relacjach Polaków z połowy XIX w." (Treder 2007: 31). Adela Kuik-Kalinowska podkreśla, że Ceynowa wyprowadza z Biblii „splendor i znaczenie dla własnych celów”, uważa nawet, że zabieg ten „ma na celu nadanie szczególnej, niemal sakralnej wartości przywoływanym kwestiom kaszubskim" (Kuik-Kalinowska 2009: 95).

Dzięki kreowaniu korzystnego obrazu dziewiętnastowiecznych Kaszub i Kaszubów zarówno biblijne, jak i wojenne etymologie ludowe Ceynowy, tworzące w Rozmòwie... trzydziestoelementową kolekcję minitekstów o atrakcyjnej formie wyrosłej z kultury ludowej, służą budowaniu kaszubskiej tożsamości etnicznej oraz prestiżu społeczności kaszubskiej. Ważną rolę odgrywa przy tym sugerowanie starożytności etymologizowanych 
nazw oraz dawności tekstu, który te etymologie zawiera. Po ponad 160 latach od swego powstania etymologie ludowe Ceynowy funkcjonują jako jeden z nośników kaszubskiej pamięci zbiorowej.

\section{Literatura}

Bartmiński J., 1977, O derywacji stylistycznej. Gwara ludowa w funkcji języka artystycznego, Lublin.

Borzyszkowski J., 2003, Pomorze - ziemia obiecana w literaturze i tradycji kaszubsko-pomorskiej, w: Obrazy ziemi stupskiej. Spoleczeństwo - administracja - kultura. Materiaty z VII Konferencji Kaszubsko-Pomorskiej, Stupsk 5-6 grudnia 2002, red.

A. Czarnik, Słupsk, s. 161-177.

Ceynowa F.S., 2007, Rozmòwa Pòlôcha z Kaszëba napisónô przez s.p. Ksãdza Szmùka z Pùcka a do drëkù pòdónô przez Sëna Wòjkòjca ze Stawòszëna. Rokù Pańsczégò 1850. Drëdżé wëdanié, z Krajobrazã Zemi Kaszëbsczé W Swiecu nad Wista ù czarnoksążnika J. Hauffégò 1865, w: F.S. Ceynowa, Rozmòwa Pòlôcha z Kaszëba. Rozmòwa Kaszëbë z Pòlôchã, oprac., wstęp i przypisy J. Treder, Gdańsk, s. 125140.

Cienkowski W., 1972, Teoria etymologii ludowej, Warszawa.

Cienkowski W., 1992, Tajemnice imion własnych, Warszawa.

Duda H., Koper M., 2009, Co znacza nazwy miejscowe? Etymologie i pseudoetymologie w ,gawędach kresowych” Katarzyny Węglickiej, w: Świat ukryty w stowach, czyli o znaczeniu gramatycznym, leksykalnym i etymologicznym, red. I. Generowicz, E. Kaczmarska, I.M. Doliński, Warszawa, s. 81-90.

Kania S., Tokarski J., 1984, Zarys leksykologii i leksykografii polskiej, Warszawa.

Kostkiewiczowa T. [tk], 1988, Etymologia ludowa, w: Słownik terminów literackich, red. J. Sławiński, Wrocław-Warszawa-Kraków-Gdańsk-Lódź, s. 132.

Kuik-Kalinowska A., 2009, Gorzki dialog, cierpki humor i problemy filozoficzne. $O$ „Rozmôvie Pôlocha s Kaszeba” i „Rozmòvie Kaszébé z Pòlôchem” Floriana Cejnowy, w: A. Kuik-Kalinowska, D. Kalinowski, Od Smętka do Stolema. Wokót literatury Kaszub, Gdańsk-Słupsk, s. 89-109.

Malinowski L., 1885, Studia nad etymologia ludowa, „Prace Filologiczne” cz. 1, s. $134-158,269-317$.

Malinowski L., 1888, Studia nad etymologia ludowa, „Prace Filologiczne” cz. 2, s. 240-262, 452-456.

Malinowski L., 1891, Studia nad etymologia ludowa, „Prace Filologiczne” cz. 3, s. 741-786.

Michow E., 2008, Legenda Kielc zamknięta w nazwie. Studium etymologiczne i kulturowe, Kielce.

Miodek J., 2002, Legenda i prawda o Kobylinie, Jutrosinie oraz Dubinie, „Forum Kobylińskie" nr 1 (30), <http://spkobylin.w.interia.pl/nazwa.htm>, 21.05.2014. 
Rogowska-Cybulska E., 2013, O motywach historycznych wpisanych $w$ etymologie ludowe pomorskich choronimów i toponimów, w: Językowy, literacki i kulturowy obraz Pomorza, red. M. Klinkosz, Z. Lica, Gdańsk, s. 85-97.

Rospond S., 1957, Klasyfikacja strukturalno-gramatyczna słowiańskich nazw geograficznych, Wrocław.

Rzetelska-Feleszko E., 2003, Rola nazw własnych dla samoidentyfikacji mniejszości narodowych i etnicznych (na przykładzie Kaszub i Łużyc), w: Języki mniejszości i języki regionalne, red. E. Wrocławska, J. Zieniukowa, Warszawa, s. 49-59.

Samp J., 1988, Jak Polak z Polakiem?, „Pomerania” nr 10, s. 9-11.

Szacka B., 2006, Czas przeszły - pamięć-mit, Warszawa.

Tołstoj N.I., 1992, Język a kultura (niektóre zagadnienia słowiańskiej etnolingwistyki), w: Etnolingwistyka 5, red. J. Bartmiński, Lublin, s. 15-25.

Treder J., 1981, Nazwy importowane w toponimii Kaszub, „Onomastica” nr 26, s. 6181.

Treder J., 2006, Ceynowa Florian Stanisław Wenancjusz, w: Język kaszubski. Poradnik encyklopedyczny, red. J. Treder, Gdańsk, s. 35-41.

Treder J., 2007, Wstęp, w: F.S. Ceynowa, Rozmòwa Pòlôcha z Kaszëbą. Rozmòwa Kaszëbë z Pòlôchã, oprac., wstęp i przypisy J. Treder, Gdańsk, s. 7-75.

Walczak B., 1999, Zarys dziejów języka polskiego, Wrocław.

Zieniukowa J., 2003, Pojęcie aksjologiczne „prestiz” a społeczna sytuacja języków mniej używanych - casus tużycczyzny i kaszubszczyzny, w: Języki mniejszości i języki regionalne, red. E. Wrocławska, J. Zieniukowa, Warszawa, s. 79-100.

Zierhofferowa Z., Zierhoffer K., 2012, Etymologie ludowe, ich funkcja i struktura, „Onomastica” nr 56, s. 15-23.

Zierhofferowa Z., Zierhoffer K., 2013, Etymologie ludowe toponimów - historycznie i współcześnie, w: Trwanie w języku... Pamięci Profesor Moniki Gruchmanowej w 10. rocznice Jej śmierci, red. A. Piotrowicz, M. Witaszek-Samborska, Poznań, s. $49-56$. 
